\title{
Induction of Systemic Resistance in Sugar- Beet against Root-Knot Nematode with Commercial Products
}

\author{
Mostafa Fatma AM*1, Khalil AE², Nour EI Deen $\mathrm{AH}^{1}$, Ibrahim ${ }^{1}$ and Dina $\mathrm{S}^{2}$ \\ ${ }^{1}$ Agricultural Zoology Department, Faculty of Agriculture, Mansoura University, Mansoura, Egypt \\ ${ }^{2}$ Nematology Division, Plant Pathology Res. Institution, Giza, Egypt
}

\begin{abstract}
The potentials of Bio-arc (a commercial formulation of the Bacillus megaterium) at the rate of $5,10,15$ and 20 $\mathrm{ml}$ and Nemastrol (a commercial formulation of active ingredients) at the rate of $0.25 \mathrm{ml}$, for induction of systemic resistance to sugar-beet var. Negma infected with $M$. incognita were conducted in two soil types. Results revealed that all treatments with tested rates were found to have nematicidal activity against nematode infection and improved plant growth parameters of sugar-beet with various levels of success. The dual application of Bio-arc+Nemastrol at the rate of $20 \mathrm{ml}+0.25 \mathrm{ml}$ proved to be the best and showed significant improvement in plant growth parameters in terms of shoot length $(92.6,127.5 \%)$ and total plant fresh weight $(91.7,370.4)$ of sugar-beet grown either in clayey or sandy soil, respectively. Among all treatments Nemastrol ranked next to oxamyl and performed the best and significantly suppressed total nematode population $(R f=1.9,2.2)$, root galling $(R G I=3.0,3.0)$, number of egg masses $(E I=3.0,3.0)$ and number of eggs / egg mass (Red. \%=76.5, 74.5) in clayey and sandy soil, respectively. However, concomitant treatment showed better results than did Bio-arc alone at four tested rates. The greatest suppression in total nematode population was recorded with clayey and sandy soil receiving the dual application of Nemastrol $(0.25 \mathrm{ml})$ and Bio-arc $(20 \mathrm{ml})$ with reproduction factor 2.2, 2.6 and reduction percentages reached 92.8, 92.6\% respectively. Leaves of sugar-beet were assayed for their biochemical profiles with respect to NPK, total cholorophyll, total carbohydrates, proteins, and phenols. Moreover, remarkable induction in such chemical constituents except phenol content was recorded with the application of Bio- arc+Nemastrol $(20 \mathrm{ml}+0.25 \mathrm{ml})$. On the other hand, activities of related enzymes i.e. Peroxidase (PO) and Polyphenol Oxidase (PPO) were evaluated in roots of sugar-beet infected with $M$. incognita. The enzymes accumulation was much greatest in Bio-arc+Nemastrol $(20+0.25 \mathrm{ml})$ treated plants compared to control as they reached their peak at day $9^{\text {th }}$ from nematode inoculation.
\end{abstract}

Keywords: Induced resistance; Enzyme activity; Meloidogyne incognita; Sugar-beet; Biochemical activities; Soil type

\section{Introduction}

Sugar-beet (Beta vulgaris L.) is considered an important root crop, which is ranked second to sugar-cane for supporting the expansion of Egyptian sugar industry. Root-knot nematodes (RKNs) Meloidogyne spp. are among the most deleterious plant pathogens since these organisms play a detectable role in limiting the productivity of such economic agriculture crop. The root -knot nematode Meloidogyne incognita (Kofoid \& White) Chitwood is among the most important nematode infesting sugar-beet. Many efforts to protect such crop from root-knot nematodes infestation are crucial. Because of the lack of plant resistance to most species of root-knot nematode as well as the environmental restrictions on nematicidal use for controlling plant parasitic nematodes, biological control and other eco-friendly disease control measures have gained recently increasing interest. The activation of the plant's own defense system through biotic and abiotic agents, called elicitors, has been considered as a focus of research only in recent years for the control of plant pathogens. The resulting elevated resistance due to an inducing agent upon infection by a pathogen is called induced systemic resistance (ISR) or systemic acquired resistance (SAR) [1].

However, induced resistance to plant parasitic nematodes has not been as extensively studied as that of fungi and bacteria. Ibrahim, et al. [2] recorded the capability of humic acid as well as thiamine at the concentration of $2000 \mathrm{ppm}$ to induce resistance in sugar-beet against M.incognita and increase the activity of polyphenol oxidase (PPO) and peroxide oxidase (PO) enzymes compared with non-infected plants. On the other hand, plant growth promoting rhizobacterium (PGPR) belonging to Bacillus spp. are being exploited commercially for plant protection to induce systemic resistance against various pests and pathogens. PGPR mediated rhizobacteria is often associated with the onset of defense mechanisms by expression of various defense related enzymes such a glucanase, chitinase, phenylalanine ammonia lyase (PAL), peroxidase (PO), and polyphenol oxidase (PPO) and accumulation of phenols [3] .In this point of view, the present work was carried out in order to study the impact of promoting growth rhizobacterium (PGR), Bacillus megaterium, Nemastrol active ingredients extract as resistance inducers to sugar-beet plant infected with $M$. incognita under greenhouse conditions.

\section{Materials and Methods}

Two greenhouse experiments were conducted at Nematological Research Unit (NERU), using sandy and clayey soil in order to evaluate the nematicidal properties of the commercial formulation of rhizobacterium, Bacillus megaterium (Bio-arc), the commercial biocide, Nemastrol against the root-knot nematode, M. incognita

*Corresponding author: Mostafa Fatma AM, Agricultural Zoology Department, Faculty of Agriculture, Mansoura University, Msansoura, Egypt, Tel: 01149073155 E-mail: mohsenfatma@hotmail.com

Received: June 13, 2014; Accepted September 27, 2014; Published October 06, 2014

Citation: Mostafa Fatma AM, Khalil AE, Nour El Deen AH, Ibrahim, Dina S (2014) Induction of Systemic Resistance in Sugar- Beet against Root-Knot Nematode with Commercial Products. J Plant Pathol Microb 5: 236. doi:10.4172/21577471.1000236

Copyright: (c) 2014 Mostafa Fatma AM, et al. This is an open-access article distributed under the terms of the Creative Commons Attribution License, which permits unrestricted use, distribution, and reproduction in any medium, provided the original author and source are credited. 
and the resulting effect on plant growth parameters of sugar-beet var. Negma. Induced resistance (IR) of such bio-agents was assayed through chemical composition and enzyme activities.

\section{Tested bio-agents}

Bio-arc: A native commercial formulation of phosphorus soluble bacterium, Bacillus megaterium $\left(25 \times 10^{6} \mathrm{cfu} / \mathrm{g}\right) @ 2.5 \mathrm{~g} / \mathrm{L}$ of distilled water, was obtained from Agricultural Research Institute, Giza, Egypt and enrolled by the Ministry of Egyptian Agriculture under No. 1087.

Nemastrol: A native commercial formulation of active ingredients containing glycosynolates $(12 \%)$, chitinase $\left(12 \times 10^{5} \mathrm{IU}\right)$, cytokinins (200 ppm), flavonoids (5\%) and $\beta 1-3$, Glucanase $\left(2 \times 10^{5} \mathrm{IU}\right) @$ the rate of $5 \mathrm{~L} /$ feddan, was obtained from Royal Company, Egypt.

Tested bio-agents rates: The tested bio- agent, Nemastrol was applied @ the rate of $0.25 \mathrm{ml} /$ pot. However, Bio-arc was added using four different rates of 5, 10, 15 and $20 \mathrm{ml} /$ pot in single application.

The chemical nematicide: Oxamyl $10 \% \mathrm{G}$; S-methyl -1(dimethylcarbamoyl)-N-[(methylcarbamoyl) oxyl] thioforminidate, was applied as a standard nematicide @ the rate of $0.3 \mathrm{~g} / \mathrm{pot}$

Experimental design: For each soil type, forty eight plastic pots (15-cm-d) containing $800 \mathrm{~g}$ steam- sterilized soil were planted with 3-5 seeds/pot of sugar-beet var. Negma, irrigated with water as needed then thinned to one seedling/pot after one month from germination. Fifteen days later, plant seedlings were inoculated with 2000 viable eggs of rootknot nematode, $M$. incognita. One week later, plants were treated with the selective materials as soil drench at the previous mentioned rates. For each soil type, four pots were treated with oxamyl @ the rate of 0.3 $\mathrm{g} /$ pot. However, four pots were left free of nematode infection and any treatment to serve as control (Ck1). Another four pots were received nematode alone and served as control (Ck2). Pots were then arranged in a randomized complete block design in a greenhouse @ $27 \pm 3^{\circ} \mathrm{C}$, with four replicates and received water as needed. Therefore, treatments for each soil type were as follows:- 1-Bio-arc @ $5 \mathrm{ml} /$ pot; 2- Bio-arc @ 10 ml/pot;3- Bio-arc@ 15 ml/pot;4-Bio-arc@ 20 ml/pot;5- Nemastrol @ $0.25 \mathrm{ml} /$ pot;6- Bio-arc @ $5 \mathrm{ml} /$ pot +Nemastrol @ $0.25 \mathrm{ml} /$ pot ;7Bio-arc@10 ml/pot+Nemastrol @ 0.25 ml/ pot;8-Bio-arc@ 15 ml/ pot+Nemastrol@0.25 ml/ pot;9-Bio-arc@20 ml/pot+Nemastrol @ $0.25 \mathrm{ml} /$ pot;10- Oxamyl (O),11- Untreated Uninoculated plants (Ck1) and 12- Nematode alone (Ck2). Plants were harvested 45 days after nematode inoculation and roots were washed free from adhering soil. Data dealing with fresh shoot and root weight, dry shoot weight, shoot and root length, were recorded. Nematodes were extracted from soil using sieving and modified Baermann technique [4]. Roots were stained in 0.01 acid fuchsin [5] and examined for the developmental stages, females, galls and egg masses under stereomicroscope. Root galling or egg masses were rated on a scale of $0-5$ where $0=$ no galls or egg masses, $1=1-2$ galls or egg masses, $2=3-10$ galls or egg masses, $3=11-30$ galls or egg masses, $4=31-100$ galls or egg masses, $5=$ more than 100 galls or egg masses per root system [6].

For each treatment, dry weight of shoot $(1 \mathrm{~g})$ was subjected to chemical analysis in order to evaluate total nitrogen, crude protein, total carbohydrate and total phenol. Samples of dried leaves were ground, wet digested and nitrogen $(\mathrm{N})$, phosphorus $(\mathrm{P})$, potassium $(\mathrm{K})$ contents were determined according to kjeldahl methods [7] A.O.A.C. (1980) described by number of researchers (Pregl, Jackson, John) [8-10].

Determination of enzymatic activities: Sugar-beet plants treated with Bio-arc $(20 \mathrm{ml} /$ pot $)$ and Nemastrol $(0.25 \mathrm{ml} /$ pot $)$ singly and concomitantly were inoculated with 2000 second juveniles of $M$. incognita and tested for enzymatic activities. The same protocol as outlined before was repeated. Roots were collected at different intervals $(0,3,9$ and 15 days after treatment and nematode inoculation) and assayed for activities of Peroxidase (PO) and Polyphenol Oxidase (PPO).

Preparation of enzyme extract: Enzyme extracts were prepared following the method described by [3] Maxwell and Bateman (1967. Dry root tissues $(0.5 \mathrm{~g})$ of each treatment were ground in $3 \mathrm{ml} \mathrm{Na}-$ phosphate buffer at $\mathrm{pH} 6.8$ in a mortar and then centrifuged at 1.500 $\mathrm{g} / 20 \mathrm{~min}$ at $6^{\circ} \mathrm{C}$. The resultant supernatant fluids were processed for enzyme assays.

Peroxidase activity (PO): Peroxidase was assayed using photochemical method as described by [11] Amako et al. The reaction mixture was added as the following sequences, $1500 \mathrm{ml}$ phosphate buffer., $480 \mathrm{ml}$ hydrogen peroxidase., $1000 \mathrm{ml}$ pyrogallol, $20 \mathrm{ml}$ sample extract. The increasing in the absorbance at $430 \mathrm{~nm}$ was recorded against blank with phosphate buffer instead of enzyme extract. One unit of enzyme activity was defined as the amount of the enzyme, which changing the optical density at $430 \mathrm{~nm}$ per min. at $25^{\circ} \mathrm{C}$ under standard assay conditions. Specific activity was expressed in units by dividing it to mg protein.

Polyphenol oxidase (PPO): Polyphenol oxidase was assayed using photochemical method as described by Coseteng and Lee [12]. The reaction mixture was added as the following sequences: 2.7 $\mathrm{ml}$ potassium phosphate buffer $90.05 \mathrm{M}, \mathrm{pH} 6.2,0.25 \mathrm{ml}$ of $0.25 \mathrm{M}$ catechol, $0.05 \mathrm{ml}$ of enzyme extract. The increasing in absorbance at $420 \mathrm{~nm}$ was measured. One unit of enzyme activity is defined as the amount of the enzyme that causes an increase of 0.001 absorbance unit per minute at $25^{\circ} \mathrm{C}$.

Data analysis: Statistically, the obtained data were subjected to analysis of variance (ANOVA) [13] (Gomez and Gomez) followed by Duncan's multiple range tests to compare means [14].

\section{Results}

The influence of the two bio-control agents namely Bio-arc (a commercial formulation of $B$. megaterium) at four tested rates $(5,10$, 15 , and $20 \mathrm{ml}$ ) and Nemastrol @ $0.25 \mathrm{ml}$ singly and concomitantly on plant growth response of sugar-beet plant var. Negma infected with $M$. incognita and grown in two soil types i.e. clayey and sandy is summarized Table 1. (Results revealed that $M$. incognita infection caused a significant reduction in plant growth parameters (shoot and root length, shoot weight) with reduction percentage in total plant fresh weight reached 35.0 and $64.0 \%$ in clayey and sandy soil respectively. Irrespective to soil type and tested rates, all treatments showed remarkable increase in plant growth parameters in terms of shoot length, shoot and root weight with various degrees. In single application, it was evident that the effectiveness of bio-arc to enhance plant growth parameters increased with the increase of addition in the two soil types. Plant growth response of sugar-beet infected with $M$. incognita was pronounced in sandy soil more than clayey soil. In sandy soil, a significant improvement in shoot length (85.8\%), plant fresh weight (174.1\%) and shoot dry weight (350.0\%) was recorded with Bioarc@ the rate of $20 \mathrm{ml} /$ plant. Similar trend was noticed with sugar-beet grown in clayey soil with percentage of increase in shoot length, total plant fresh weight and dry shoot weight reached 70.4, 41.7 and $180.0 \%$, respectively. However, Nemastrol at the rate of $0.25 \mathrm{ml}$ resulted a pronounced improvement in plant growth parameters in terms of shoot length $(100.0,10.8 \%)$, total plant fresh weight $(70.5,44.4 \%)$ and shoot dry weight $(200.0,150.0 \%)$ of sugar-beet grown in clayey and sandy 
Citation: Mostafa Fatma AM, Khali AE, Nour El Deen AH, Ibrahim, Dina S (2014) Induction of Systemic Resistance in Sugar- Beet against Root-Knot Nematode with Commercial Products. J Plant Pathol Microb 5: 236. doi:10.4172/2157-7471.1000236

Page 3 of 7

\begin{tabular}{|c|c|c|c|c|c|c|c|c|c|}
\hline \multirow{2}{*}{ Treatments } & \multirow[b]{2}{*}{ Rates/ml } & \multicolumn{6}{|c|}{ *Plant growth response } & \multirow{2}{*}{$\begin{array}{l}\text { Shoot Dry } \\
\text { wt.(g) }\end{array}$} & \multirow[b]{2}{*}{ Inc. $\%$} \\
\hline & & $\begin{array}{l}\text { Shoot Length } \\
(\mathrm{cm})\end{array}$ & Inc. $\%$ & $\begin{array}{l}\text { Shoot fresh } \\
\text { wt. (g.) }\end{array}$ & $\begin{array}{l}\text { Root fresh } \\
\text { wt. (g.) }\end{array}$ & $\begin{array}{c}\text { Total Plant fresh } \\
\text { wt.(g) }\end{array}$ & Inc. $\%$ & & \\
\hline \multicolumn{10}{|c|}{ Clayey Soil } \\
\hline \multirow{4}{*}{ Bio-arc } & \multirow{4}{*}{$\begin{array}{l}5 \\
10 \\
15 \\
20\end{array}$} & $18.3^{e}$ & 35.6 & $10.9^{\text {de }}$ & $5.8^{d}$ & 16.7 & 26.5 & $1.7^{\mathrm{ef}}$ & 70.0 \\
\hline & & $21.0^{d}$ & 55.6 & $11.3^{c-e}$ & $5.8^{d}$ & 17.1 & 29.5 & $1.7^{\text {ef }}$ & 70.0 \\
\hline & & $22.0^{\text {cd }}$ & 63.0 & $11.7^{\mathrm{cee}}$ & $6.2^{\mathrm{d}}$ & 17.9 & 35.6 & $2.2^{\mathrm{de}}$ & 120.0 \\
\hline & & $23.0^{c}$ & 70.4 & $12.0^{\mathrm{cd}}$ & $6.7^{\mathrm{cd}}$ & 18.7 & 41.7 & $2.8^{\mathrm{cd}}$ & 180.0 \\
\hline Nemastrol & 0.25 & $27.0^{\mathrm{a}}$ & 100.0 & $13.7^{\mathrm{a}-\mathrm{c}}$ & $8.8^{\mathrm{a}}$ & 22.5 & 70.5 & $3.0^{\mathrm{b}-\mathrm{d}}$ & 200.0 \\
\hline \multirow{4}{*}{ Bio-arc+Nemastrol } & \multirow{4}{*}{$\begin{array}{c}5+0.25 \\
10+0.25 \\
15+0.25 \\
20+0.25\end{array}$} & $25.0^{b}$ & 85.2 & $12.4^{\mathrm{b}-\mathrm{d}}$ & $8.5^{\mathrm{ab}}$ & 20.9 & 58.3 & $3.2^{\mathrm{a}-\mathrm{c}}$ & 220.0 \\
\hline & & $25.3^{\mathrm{ab}}$ & 87.4 & $13.6^{\mathrm{a}-\mathrm{c}}$ & $8.7^{\mathrm{a}}$ & 22.3 & 68.9 & $3.5^{\mathrm{a}-\mathrm{c}}$ & 250.0 \\
\hline & & $25.5^{\mathrm{ab}}$ & 88.9 & $14.9^{\mathrm{ab}}$ & $8.5^{\mathrm{ab}}$ & 23.4 & 77.3 & $3.7^{\mathrm{ab}}$ & 270.0 \\
\hline & & $26.0^{\mathrm{ab}}$ & 92.6 & $15.9^{\mathrm{a}}$ & $9.4^{\mathrm{a}}$ & 25.3 & 91.7 & $3.9^{a}$ & 290.0 \\
\hline \multicolumn{2}{|l|}{ Oxamyl } & $18.8^{e}$ & 39.3 & $11.9^{\text {cd }}$ & $7.6^{\mathrm{bc}}$ & 19.5 & 47.7 & $1.3^{f}$ & 30.0 \\
\hline \multicolumn{2}{|c|}{ Plant free of $\mathrm{N}$} & $13.8^{f}$ & 2.2 & $11.1 \mathrm{~d}^{\mathrm{e}}$ & $9.2^{\mathrm{a}}$ & 20.3 & 53.8 & $1.2^{f}$ & 20.0 \\
\hline \multicolumn{2}{|l|}{$\mathrm{N}$ alone } & $13.5^{f}$ & 0.0 & $9.3^{e}$ & $3.9^{\mathrm{e}}$ & 13.2 & 0.0 & $1.0^{f}$ & 0.0 \\
\hline \multicolumn{10}{|c|}{ Sandy Soil } \\
\hline \multirow{4}{*}{ Bio-arc } & \multirow{4}{*}{$\begin{array}{c}5 \\
10 \\
15 \\
20\end{array}$} & $12.9^{\text {ef }}$ & 7.5 & $2.1^{f}$ & $2.5^{\mathrm{ef}}$ & 4.6 & 70.4 & $0.6^{g-i}$ & 50.0 \\
\hline & & $14.5^{\mathrm{e}}$ & 20.8 & $2.1^{\text {ef }}$ & $2.9^{\mathrm{d}-\mathrm{f}}$ & 5.0 & 85.2 & $0.9^{f-h}$ & 125.0 \\
\hline & & $17.3^{\mathrm{d}}$ & 44.2 & $2.9^{\mathrm{de}}$ & $2.5^{\mathrm{e}-\mathrm{g}}$ & 5.4 & 100.0 & $1.5^{\mathrm{d}}$ & 275.0 \\
\hline & & $22.3^{\mathrm{c}}$ & 85.8 & $4.4^{c}$ & $3.0^{\text {de }}$ & 7.4 & 174.1 & $1.8^{\mathrm{cd}}$ & 350.0 \\
\hline Nemastrol & 0.25 & $13.3^{\text {ef }}$ & 10.8 & $2.1^{f}$ & $1.8^{\mathrm{gh}}$ & 3.9 & 44.4 & $1.0^{\mathrm{fg}}$ & 150.0 \\
\hline \multirow{4}{*}{ Bio-arc+Nemastrol } & \multirow{4}{*}{$\begin{array}{l}5+0.25 \\
10+0.25 \\
15+0.25 \\
20+0.25\end{array}$} & $18.0^{\mathrm{d}}$ & 50.0 & $3.1^{\mathrm{d}}$ & $2.2^{\mathrm{f}-\mathrm{h}}$ & 5.3 & 96.3 & $1.0^{e f}$ & 150.0 \\
\hline & & $22.5^{\mathrm{c}}$ & 87.5 & $5.4^{\mathrm{b}}$ & $4.5^{c}$ & 9.9 & 266.7 & $2.2^{\mathrm{ab}}$ & 450.0 \\
\hline & & $25.5^{\mathrm{ab}}$ & 112.5 & $5.7^{\mathrm{b}}$ & $5.3^{b}$ & 11.0 & 307.4 & $2.1^{b c}$ & 425.0 \\
\hline & & $27.3^{\mathrm{a}}$ & 127.5 & $6.7^{\mathrm{a}}$ & $6.0^{\mathrm{a}}$ & 12.7 & 370.4 & $2.5^{\mathrm{a}}$ & 525.0 \\
\hline \multicolumn{2}{|l|}{ Oxamyl } & $18.5^{\mathrm{d}}$ & 54.2 & $1.3^{9}$ & $1.6^{\mathrm{h}}$ & 2.9 & 7.4 & $0.6^{\mathrm{hi}}$ & 50.0 \\
\hline \multicolumn{2}{|c|}{ Plant free of $\mathrm{N}$} & $24.0^{\mathrm{bc}}$ & 100.0 & $4.2^{\mathrm{c}}$ & $3.3^{d}$ & 7.5 & 177.8 & $1.5^{\mathrm{de}}$ & 275.0 \\
\hline \multicolumn{2}{|l|}{$\mathrm{N}$ alone } & $12.0^{f}$ & 0.0 & $1.0^{\mathrm{g}}$ & $1.7^{\mathrm{h}}$ & 2.7 & 0.0 & $0.4^{i}$ & 0.0 \\
\hline
\end{tabular}

Means in each column followed by the same letter(s) did not differ at $\mathrm{P} \leq 0.05$ according to Duncan`s multiple range test Each value presented the mean of four replicates $\mathrm{N}=$ M. incognita (2000 eggs/ plant)

Table 1 : Impact of Bio-arc (Bacillusmegaterium) and Nemastrol ( a mixture of active ingredients) on plant growth response of sugar-beet var. Negma grown in two soil types infected with $M$. incognita under greenhouse conditions $\left(27 \pm 3^{\circ} \mathrm{C}\right)$.

\begin{tabular}{|c|c|c|c|c|c|c|c|c|c|c|}
\hline Treatments & Rates/ ml & $\begin{array}{l}\text { No. of } \\
\text { galls* }\end{array}$ & $\mathbf{R} \mathbf{G I}^{* *}$ & $\begin{array}{c}\text { No. of } \\
\text { eggmasses }\end{array}$ & $\mathrm{El}^{*}$ & $\begin{array}{c}\text { No. of eggs/ } \\
\text { eggmass }\end{array}$ & $\begin{array}{c}\text { Nematode } \\
\text { population in Soil }\end{array}$ & $\begin{array}{c}\text { Females } \\
\text { population in Root }\end{array}$ & $\begin{array}{c}\text { Final population } \\
\text { (Pf) }\end{array}$ & $\mathbf{R f}^{\star \star *}$ \\
\hline \multicolumn{11}{|c|}{ Clayey soil } \\
\hline \multirow{4}{*}{ Bio-arc } & 5 & $32.0^{\mathrm{b}}$ & 4.0 & $22.3^{\mathrm{b}}$ & 3.0 & $1009.95^{b}$ & $584.5^{b}$ & $34.5^{\mathrm{b}}$ & 23141.4 & 11.6 \\
\hline & 10 & $29.8^{b}$ & 3.0 & $20.8^{b}$ & 3.0 & $874.95^{c}$ & $439.5^{c}$ & $33.5^{\mathrm{b}}$ & 18672.5 & 9.3 \\
\hline & 15 & $20.5^{c}$ & 3.0 & $17.5^{\mathrm{c}}$ & 3.0 & $689.95^{d}$ & $399.5^{d}$ & $22.5^{c}$ & 12496.4 & 6.2 \\
\hline & 20 & $20.0^{\text {cd }}$ & 3.0 & $14.5^{\mathrm{cd}}$ & 3.0 & $587.45^{\mathrm{e}}$ & $388.5^{\mathrm{e}}$ & $21.3^{\text {cd }}$ & 8927.8 & 4.5 \\
\hline Nemastrol & 0.25 & $13.8^{\mathrm{e}}$ & 3.0 & $11.3^{e}$ & 3.0 & $312.45^{j}$ & $299.5^{k}$ & $15.8^{\mathrm{e}}$ & 3846.0 & 1.9 \\
\hline \multirow{4}{*}{ Bio-arc +Nemastrol } & $5+0.25$ & $19.3^{\mathrm{cd}}$ & 3.0 & $14.3^{\text {cd }}$ & 3.0 & $489.95^{f}$ & $372.5^{f}$ & $20.5^{\mathrm{cd}}$ & 7399.3 & 3.7 \\
\hline & $10+0.25$ & $18.0^{c-e}$ & 3.0 & $13.0^{\text {de }}$ & 3.0 & $417.45^{\mathrm{g}}$ & $361.2^{\mathrm{g}}$ & $19.5^{c-e}$ & 5807.6 & 2.9 \\
\hline & $15+0.25$ & $16.0^{\text {de }}$ & 3.0 & $11.8^{\mathrm{de}}$ & 3.0 & $392.45^{\mathrm{h}}$ & $359.5^{\mathrm{h}}$ & $18.3^{c-e}$ & 5008.7 & 2.5 \\
\hline & $20+0.25$ & $15.8^{\text {de }}$ & 3.0 & $11.3^{e}$ & 3.0 & $349.95^{i}$ & $337.5^{i}$ & $17.5^{\text {de }}$ & 4309.4 & 2.2 \\
\hline Oxamyl & & $7.3^{f}$ & 2.0 & $10.0^{f}$ & 2.0 & $249.95^{k}$ & $300.5^{j}$ & $10.3^{f}$ & 2810.3 & 1.4 \\
\hline $\mathrm{N}$ alone & & $53.5^{\mathrm{a}}$ & 4.0 & $43.8^{a}$ & 4.0 & $1339.95^{a}$ & $1399.5^{\mathrm{a}}$ & $54.8^{a}$ & 60145.6 & 30.0 \\
\hline \multicolumn{11}{|c|}{ Sandy soil } \\
\hline \multirow{4}{*}{ Bio-arc } & 5 & $41.5^{\mathrm{b}}$ & 4.0 & $33.3^{\mathrm{b}}$ & 4.0 & $1074.95^{\mathrm{b}}$ & $1443.8^{\mathrm{ab}}$ & $45.5^{\mathrm{b}}$ & 37285.9 & 18.6 \\
\hline & 10 & $41.3^{b}$ & 4.0 & $30.5^{c}$ & 3.0 & $964.95^{c}$ & $1000.5^{\mathrm{a}-\mathrm{c}}$ & $44.0^{\mathrm{b}}$ & 30476.0 & 15.2 \\
\hline & 15 & $17.3^{d}$ & 4.0 & $30.3^{c}$ & 3.0 & $862.45^{d}$ & $810.0^{\mathrm{bc}}$ & $37.0^{c}$ & 26979.7 & 13.5 \\
\hline & 20 & $24.8^{d}$ & 3.0 & $22.5^{d}$ & 3.0 & $736.25^{e}$ & $507.6^{\mathrm{bc}}$ & $26.3^{d}$ & 17099.5 & 8.5 \\
\hline Nemastrol & 0.25 & $14.3^{\mathrm{fg}}$ & 3.0 & $11.5^{\mathrm{fg}}$ & 3.0 & $351.25^{j}$ & $279.5^{c}$ & $15.0^{f}$ & 4333.9 & 2.2 \\
\hline \multirow{4}{*}{ Bio-arc +Nemastrol } & $5+0.25$ & $23.8^{d}$ & 3.0 & $22.3^{d}$ & 3.0 & $574.95^{f}$ & $400.5^{c}$ & $24.8^{\mathrm{de}}$ & 13246.7 & 6.6 \\
\hline & $10+0.25$ & $18.5^{\mathrm{e}}$ & 3.0 & $14.5^{\mathrm{e}}$ & 3.0 & $509.95^{9}$ & $384.5^{c}$ & $21.8^{\mathrm{de}}$ & 7800.6 & 3.9 \\
\hline & $15+0.25$ & $18.3^{e f}$ & 3.0 & $12.8^{\text {ef }}$ & 3.0 & $449.95^{h}$ & $362.5^{c}$ & $21.3^{e}$ & 6143.2 & 3.0 \\
\hline & $20+0.25$ & $16.3^{\text {ef }}$ & 3.0 & $11.8^{\mathrm{ef}}$ & 3.0 & $417.45^{i}$ & $347.5^{c}$ & $21.0^{\mathrm{e}}$ & 5294.4 & 2.6 \\
\hline \multicolumn{2}{|l|}{ Oxamyl } & $11.5^{\mathrm{g}}$ & 3.0 & $11.0^{\mathrm{g}}$ & 3.0 & $117.45^{\mathrm{k}}$ & $360.5^{j}$ & $12.5^{f}$ & 1665.0 & 0.8 \\
\hline \multicolumn{2}{|l|}{$\mathrm{N}$ alone } & $58.5^{a}$ & 4.0 & $50.5^{a}$ & 4.0 & $1379.95^{\mathrm{a}}$ & $2069.5^{a}$ & $61.0^{\mathrm{a}}$ & 71819.8 & 35.9 \\
\hline
\end{tabular}

*Each value presented the mean of four replicates $N=M$. incognita (2000 eggs/ plant ). Means in each column followed by the same letter(s) did not differ at $P \leq 0.05$ according to Duncan's multiple range test. ** Root gall index (RGI) or egg masses index (EI) was determined according to the scale given by Taylor and Sasser as follows : $0=$ no galls or egg masses, $1=1-2$ galls or egg masses , $2=3-10$ galls of egg masses, $3=11-30$ galls or egg masses, $4=31-100$ galls or egg masses and $5=$ more than 100 galls or egg masses ${ }^{* *}$ Reproudction factor $(\mathrm{Rf})=$ No. of eggs per root + Nematode population in soil + No. of developmental stages + No. of females $/$ No. of eggs inocula

Table 2: Impact of Bio-arc and Nemastrol (a mixture of active ingredients) singly and concomitantly on the development and reproduction of $M$. incognita infecting sugarbeet var. Negma grown in two soil types under greenhouse conditions at $27 \pm 3^{\circ} \mathrm{C}$. 


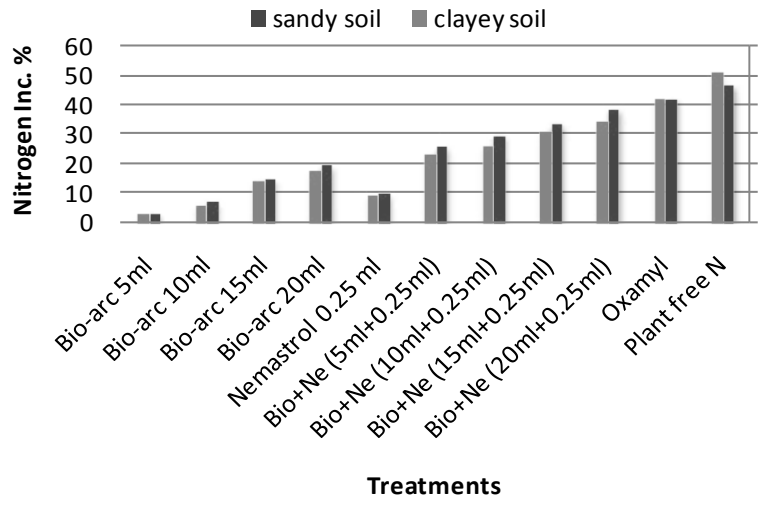

Figure 1: Percentage of Nitrogen in leaves of sugar-beet var. Negma grown in clayey and sandy soil treated with certain bio-agents as resistance inducers under the infection of Meloidogyne incognita.

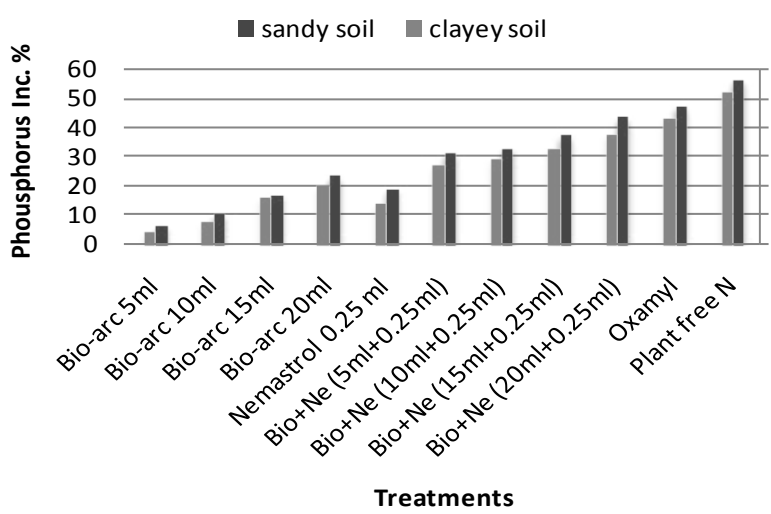

Figure 2: Percentage of phosphorus in leaves of sugar-beet var. Negma grown in clayey and sandy soil treated with certain bio-agents as resistance inducers under the infection of Meloidogyne incognita.

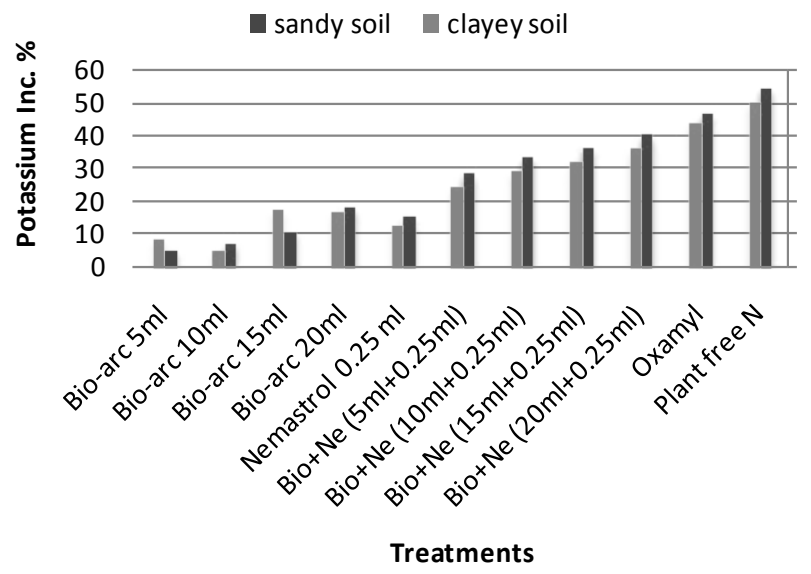

Figure 3: Percentage of potassium in leaves of sugar-beet var. Negma grown in clayey and sandy soil treated with certain bio-agents as resistance inducers under the infection of Meloidogyne incognita.

soil respectively. In concomitant treatment, Bio- $\operatorname{arc}(20 \mathrm{ml})+\mathrm{Nemastrol}$ $(0.25 \mathrm{ml})$ was the best and showed significant improvement in plant growth parameters in terms of shoot length $(92.6,127.5 \%)$ and total plant fresh weight $(91.7,370.4)$ of sugar-beet grown either in clayey or sandy soil, respectively. Oxamyl as a standard nematicide showed moderate improvement in pervious criteria of sugar-beet grown in clayey soil with increase percentages 39.3 , and 47.4 respectively. Similar trend was noticed with shoot length $(54.2 \%)$ and dry shoot weight (50\%) of sugar-beet grown in sandy soil treated with oxamyl.

Regarding the impact of Bio-arc and Nemastrol singly and concomitantly on the development and reproduction of the rootknot nematode, $M$. incognita infecting sugar-beet grown in clayey and sandy soil is documented (Table 2). Irrespective to soil type and tested rates results revealed that total nematode population was significantly suppressed with all tested treatments with reproduction factor ranged from 1.4 to 11.6 in clayey soil and from 0.8 to 18.6 in sandy soil compared to inoculated plants $(\mathrm{Rf}=30.0,35.9)$ respectively. Among tested treatments, Nemastrol significantly suppressed total nematode population $(\mathrm{RF}=1.9,2.2)$, root galling $(\mathrm{RGI}=3.0,3.0)$, number of egg masses (EI $=3.0,3.0)$ and number of eggs $/ 10$ egg masses (Red. $\%=76.5$, 74.6) in clayey and sandy soil, respectively. However, concomitant treatment showed better results than did bio-arc alone at four tested rates. Among the concomitant treatment the greatest reduction in total nematode population was recorded in clayey and sandy soil which received the dual application of Bio-arc $(20 \mathrm{ml})$ and Nemastrol $(0.25$ $\mathrm{ml}$ ) with reproduction factor 2.2, 2.6 and reduction percentages reached 92.8, 92.6\%. Meanwhile, total nematode population was significantly suppressed with oxamyl introduced to clayey soil $(\mathrm{Rf}=1.4)$ and sandy soil $(\mathrm{Rf}=0.8)$ relative to control plants where $\mathrm{Rf}=30.0$ and 35.9 , respectively. Nevertheless, number of eggs/ egg mass were significantly suppressed with oxamyl application with percentage of reduction amounted to 76.7 and $74.5 \%$ in clayey and sandy soil respectively.

\section{Biochemicals activities}

Nitrogen, phosphorus and potassium contents: NPK contents were significantly suppressed due to nematode infection with reduction percentages $34.1,35.5$ and $39.2 \%$ in clayey soil and $32.2,37.5$ and $39.1 \%$ in sandy soil. However, a remarkable induction in NPK content was recorded with the application of Bio- arc + Nemastrol $(20 \mathrm{ml}+0.25 \mathrm{ml})$ with $\%$ of increase amounted to $34.94,41.40,48.43$ and 39.55, 45.0, 48.99 in clayey and sandy soil respectively (Figures 1-3).

Total chlorophyll content: Chlorophyll $a$ and $b$ were moderately affected due to nematode infection with reduction $\%$ in total chlorophyll reached 32.5 and $32.3 \%$ in clayey and sandy soil respectively. Application of such treatments revealed a considerable induction with the dual application of Bio + Nemastrol $(20 \mathrm{ml}+0.25 \mathrm{ml})$ and oxamyl as well with \% of increased reached 37.0, 42.6 and 38.6, $40.9 \%$ in clayey and sandy soil consecutively (Figure 4).

Total carbohydrates: Total carbohydrates were significantly suppressed due to nematode infection with reduction percentage 20.38 and $16.9 \%$ in clayey and sandy soil respectively. The highest increase was recorded in leaves of sugar-beet treated with Bio-arc+Nemastrol $(20 \mathrm{ml}+0.25 \mathrm{ml})$ with values 13.4 and $15.3 \%$ in clayey and sandy soil respectively (Figure 5).

Crude proteins: Untreated sugar-beet infected with $M$. incognita exhibited significant reduction in total proteins as compared with untreated uninoculated plants with percentage of reduction reached 34.1 and $32.1 \%$ in clayey and sandy soil respectively. Among all tested compounds, the highest increase percentage in crude proteins was obtained with oxamyl (43.4 and $42.2 \%$ ) in clayey and sandy soil, respectively (Figure 6) followed by Bio-arc+Nemastrol $(20 \mathrm{ml}+0.25$ $\mathrm{ml}$ ) with values averaged 35.0 and $39.2 \%$ in clayey and sandy soil, 


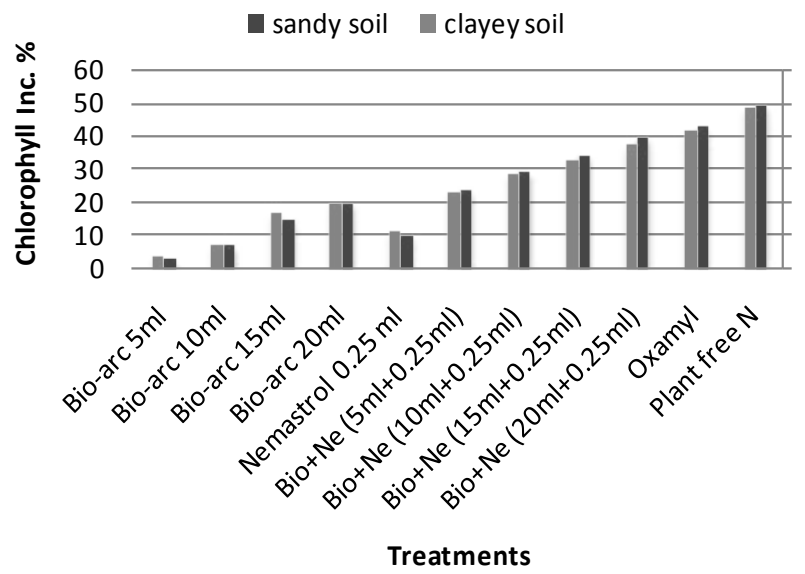

Figure 4: Percentage of total chlorophyll in leaves of sugar-beet var. Negma grown in clayey and sandy soil treated with certain bio-agents as resistance inducers under the infection of Meloidogyne incognita.

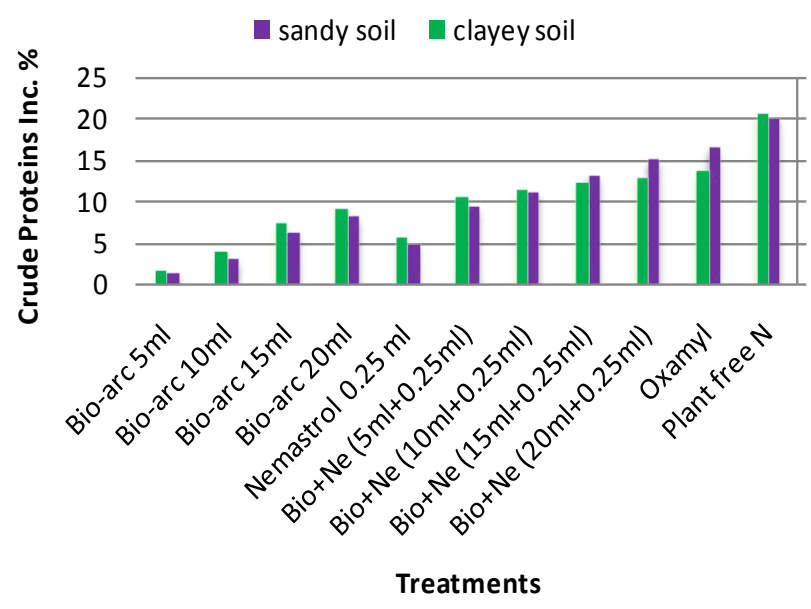

Figure 5: Percentage of total carbohydrates in leaves of sugar-beet var. Negma grown in clayey and sandy soil treated with certain bio-agents as resistance inducers under the infection of Meloidogyne incognita.

respectively.

Phenol content: The total phenol evaluated in leaves of sugar-beet infected with $M$. incognita revealed a moderate enhancement compared to control plants. However, phenol content showed different degrees of reduction in all treatments compared to untreated uninoculated plants grown in clayey and sandy soil. (Figure 7)

Defense related proteins: The tested materials viz. Bio-arc (20 $\mathrm{ml})$, Nemastrol $(0.25 \mathrm{ml})$, Bio-arc+Nemastrol $(20 \mathrm{ml}+0.25 \mathrm{ml})$ and oxamyl as well differed in their ability to stimulate Peroxidase (PO) and Polyphenol Oxidase (PPO) activities in sugar-beet plant inoculated with M.incognita (Figure 8). In untreated uninoculated plants, the activities of PO and PPO remained higher and attained their peak at the $9^{\text {th }}$ day and thereafter a decline was noticed at $15^{\text {th }}$ day. On the other hand, the least induction of PO and PPO was recorded with plants untreated and inoculated with nematodes and showed slight decline 3 days after nematode inoculation then increased and reached their peak at $9^{\text {th }}$ day. However, increased PO and PPO activities were more pronounced in Bio-arc+Nemastrol $(20 \mathrm{ml}+0.25 \mathrm{ml})$ followed by oxamyl then Nemastrol compared to untreated inoculated plants. In such treatments, the dual application Bio-arc + Nemastrol performed the best since PO\& PPO activities were increased and reached their peak at the $3^{\text {rd }}$ day after nematode inoculation then declined at $9^{\text {th }}$ day followed by slightly increment at $15^{\text {th }}$ day. Meanwhile, the increased activity of PO \&PPO remained higher in plants treated with oxamyl and reached their peak at 9 th day after nematode inoculation.

\section{Discussion}

Induction of systemic resistance (ISR) of plants against pathogens is a widespread phenomenon that has been intensively investigated in fungi and bacteria with respect to its potential use in plant protection. However, little attention has been given to nematode pests. Acquired or induced resistance can be achieved by inoculating a plant with incompatible or weak pathogens or by applying biotic or abiotic inducers [15]. The root-knot nematode, $M$. incognita caused a significant reduction in plant growth parameters (shoot and root length, shoot weight) with reduction percentage in total plant fresh weight reached 35.0 and $64.0 \%$ in clayey and sandy soil respectively. Application of

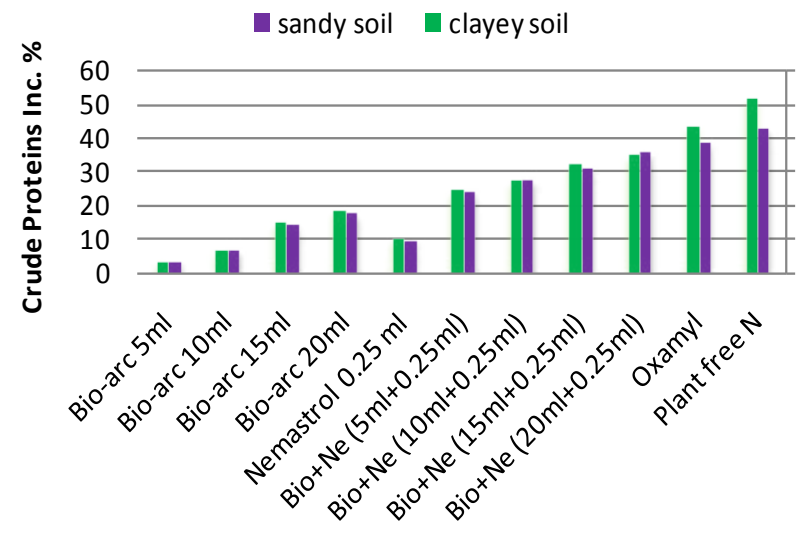

Treatments

Figure 6: Percentage of crude proteins in leaves of sugar-beet var. Negma grown in clayey and sandy soil treated with certain bio-agents as resistance inducers under the infection of Meloidogyne incognita.

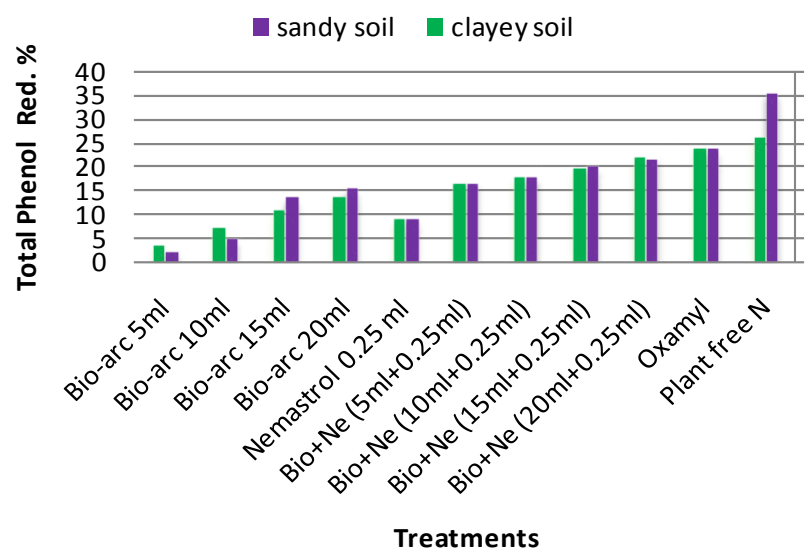

Figure 7: Percentage of total phenol in leaves of sugar-beet var. Negma grown in clayey and sandy soil treated with certain bio-agents as resistance inducers under the infection of Meloidogyne incognita. 
A

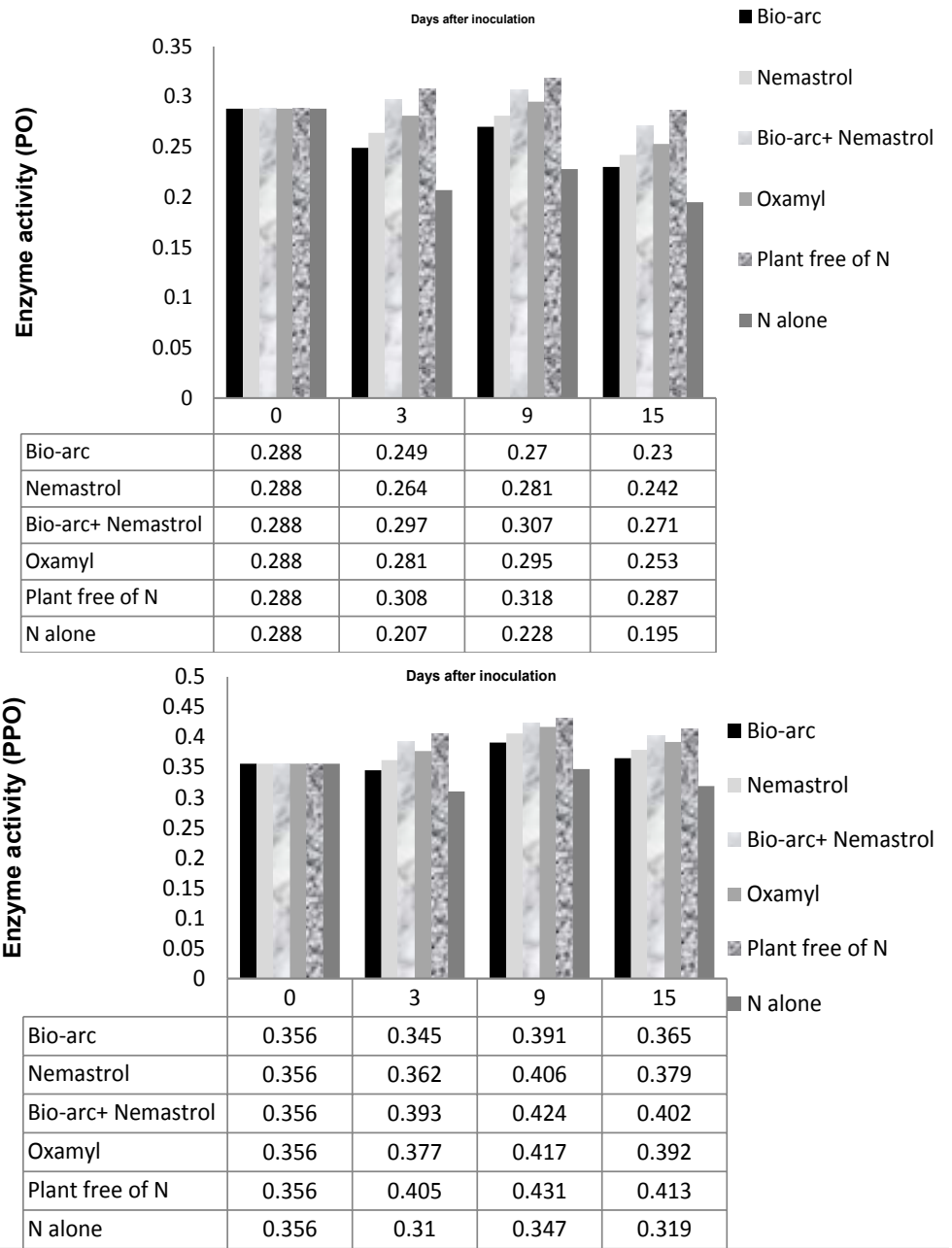

Figure 8: Impact of Bio-arc and Nemastrol as biotic resistance inducers on peroxidase (PO) and polyphenol oxidase (PPO) activities in roots of sugar-beet var. Negma after $0,3,9$ and 15 days of Meloidogyne incognita inoculation. $A=$ peroxidase activity, $B=$ polyphenol oxidase activity.

phosphorus solubilizing bacterium (PSB), B. megaterium singly or concomitantly with Nemastrol has potential as a promising biocontrol candidate against root-knot nematode, $M$. incognita infecting sugarbeet var. Negma. As for single application, the effectiveness of Bio-arc to enhance plant growth parameters increased with rates increase in the two soil types.

Plant growth response of sugar-beet infected with $M$. incognita was more pronounced in sandy soil than clayey soil. In sandy soil, a significant improvement in shoot length, plant fresh weight and shoot dry weight was recorded with Bio-arc @ the rate of $20 \mathrm{ml} /$ plant. This result support the findings of El-Deriny and Ibrahim $[16,17]$. However, in concomitant treatment, Bio- arc + Nemastrol $(20 \mathrm{ml}+0.25 \mathrm{ml})$ performed the best and showed significant improvement in plant growth parameters in terms of shoot length $(92.6 ; 127.5 \%)$ and total plant fresh weight $(91.7 ; 370.4 \%)$ of sugar- beet grown either in clayey or sandy soil. The presence of cytokinins in Nemastrol suggests a dynamic role for lateral root development. Irrespective to soil type and rates of application, total nematode population, root galling, number of egg masses and number of eggs/ egg mass were significantly suppressed with all treatments of Bio-arc and/or Nemastrol. The phosphate solubilizing bacterium (PSB) B. megaterium is considered a microorganism capable of dissolving the unavailable phosphorus compounds in soil rendering them available for growing crops [18]. Increased phosphorus concentration may lead to reduction in root-knot nematodes. B. megaterium has been evaluated for their effects on a variety of root-knot nematodes $[16,17,19,20]$ reported that $B$. megaterium greatly reduced numbers of galls, females and egg masses of $M$. incognita in the roots of sugar-beet followed by B.subtilis, Paecilomyces lilacinus, P. fumosoreus and Trichoderma album respectively. Furthermore, $B$. megaterium can extensively colonize the rhizosphere and reduce the sugar-beet cyst nematode infection under greenhouse trials [21]. B. megaterium produce antibiotic compounds [22] although no compounds from B. megaterium have been reported with activity against nematodes.

Nevertheless, Nemastrol performed the best and significantly suppressed total nematode population; root galling, number of egg masses and number of eggs /egg mass in clayey and sandy soil. The suppressive effect of such product could be attributed to the presence of mixture of enzymes i.e. chitinase and glucanase that dissolve chitin of nematode egg shell. However, concomitant treatment using Nemastrol+ Bio-arc showed better results than did Bio-arc alone at four tested rates. The greatest reduction in total nematode population was recorded with clayey and sandy soil receiving the dual application of Bio-arc (20 
$\mathrm{ml})$ and Nemastrol $(0.25 \mathrm{ml})$ with reproduction factor and reduction percentage reached $2.2 ; 2.6$ and $92.8 ; 92.6 \%$ respectively.

The impact of screened treatments on chemical components viz. NPK, chlorophyll, total carbohydrates, crude protein and total phenol in sugar-beet leaves infected with $M$. incognita revealed a remarkable induction in chemical constituents with the application of Bioarc + Nemastrol $(20 \mathrm{ml}+0.25 \mathrm{ml})$. Conversely, the highest increase in total phenol percentage was recorded with untreated inoculated plants as a hypersensitive reaction (HR) to nematode infection. Plants are endowed with defense genes which are quiescent in healthy plants. When these genes are activated with various factors they induce systemic resistance against disease. Rhizobaceria induce systemic resistance by activation of various defense-related enzymes viz. PO, PPO and PAL. Recently, research work has demonstrated that the bio-agent Pseudomonas fluorescens might stimulate the production of biochemical compounds associated with the host defense [23]. Of these, early induction of peroxidase is more important as it is the first enzyme in the phenylpropanoid pathway, which leads to production of phytoalexin and phenolic substances leading the formation of lignin [24]. Conspicuously, the current investigation recorded the higher activity of Peroxidase in plants treated with Bio-arc+Nemastrol ( 20 $\mathrm{ml}+0.25 \mathrm{ml}$ ) and reached its peak at 9 days generating the speculation of induced defense responses in sugar-beet infected with M. incognita. Peroxidase activity in roots is important in the reinforcement of cell walls at the border of infection in resistant plants and that are considered as important components of active defense response of nematode invaded tissue [25]. The trend of increasing PPO activity was similar to that of PO in all treatments. Increased activity of Peroxidase (PO) or Polyphenol Oxidase (PPO) has been elicited by biocontrol agent strains in different plants [26,27]. Finally it can be concluded that use of such inducers viz. Bio-arc and Nemastrol singly and concomitantly represent a promising new approach for the control of the target root-knot nematode, $M$. incognita infecting sugar- beet within an environmental friendly integrated pest management via enhancing the resistance of plant to nematode.

\section{References}

1. Hammerschmidt R, Kuc S (1995) Induced resistance to disease in plants Kluwer Academic Publishers, Dordrecht L., The Netherlands, p.182.

2. Dina SS, Ibrahim AH, Nour El-Deen, Khalil AE, Fatma AM Mostafa (2013). Induction of Systemic Resistance in sugar- beet infected with Meloidogyne incognita by humic acid, hydrogen peroxide, thiamine and two amino acids. Egyptian Journal of Agronematology, 1: 22-41.

3. Maxwell DP, Bateman DF (1967) Changes in the activity of oxidases in extracts of Rhizoctonia infected bean hypocotyls in relation to lesion maturation. Phytopathol, 57: 123-136.

4. Goodey JB (1957) Laboratory methods for work with plant and soil nematodes. Tech. Bull. No.2 Min. Agric. Fish Ed. London pp.47.

5. Bybd DW, Kirkpatrick T, Barker KR (1983) An improved technique for clearing and staining plant tissues for detection of nematodes. J Nematol 15: 142-143.

6. Taylor AL, Sasser JN (1978) Biology, identification and control of root-knot Nematodes (Meloidogyne spp.) Coop. pub. Dept. plant pathol. North Carolina State Univ. and U.S. Agency Int. Dev. Raleigh, N.C. 111 pp.

7. AOAC (1980) "Official methods of analysis" Twelfth Ed.Published by the Association of Official Analytical chemists, Benjamin, France line station, Washington. Dc.

8. Pregl E (1945) Quantative organic micro-analysis J. Chundril. London.

9. Jackson ML (1967) Soil Chemical Analysis. Printic Hall of India, New Delhi 144 197
10. John MK (1970) Colorimetric determination of phosphorus in soil and plant material with ascorbic acid. Soil Sci. 109: 214-220.

11. Amako A, Ghen GX, Asala K (1994) Separate assays specific for the ascorpate peroxides and guaiacol peroxidase and for the chloroplastic and cytosolic isozyme of ascorbate peroxidase in plants. Plant cell Physiol., 53: 497-507.

12. Coseteng MY, Lee CY (1987) Change in apple polyphenoloxidase and polyphenol concentrations in relation to degree of browning. J. Food Sci. 52 985-989.

13. Gomez KA, Gomez AA (1984) Statistical Procedures for Agriculture Research. June Wiley \& Sons. Inc. New York.

14. Duncan DB (1955) Multiple range and multiple, F-test. Biometrics 11: 1-42

15. Oka Y, Cohen Y, Spiegel Y (1999) Local and Systemic Induced Resistance to the Root-Knot Nematode in Tomato by DL-beta-Amino-n-Butyric Acid. Phytopathology 89: 1138-1143.

16. El-Deriny, Marwa M (2009) Studies on certain nematode pests parasitizing some ornamental plants. Ms. Thesis, Fac. Agric., Mansoura Univ., 135pp.

17. Ibrahim, Dina SS (2010) Studied on nematodes associated with sugar-beet plant roots in Dakahlia governorate. M. Sc. Thesis, Fac. Agric. Mansoura Univ., $108 \mathrm{pp}$.

18. Radwan SM (1983) Effect of inoculation with phosphate dissolving bacteria on some nutrients uptake from newly cultivated soil. M.Sc. Thesis, Fac. Agric. Ain Shams Univ. $184 \mathrm{pp}$

19. El-Hadad ME, Mustafa MI, Selim ShM, El-Tayeb TS, Mahgoob AE, et al (2011) The nematicidal effect of some bacterial biofertilizers on Meloidogyne incognita in sandy soil. Braz J Microbiol 42: 105-113.

20. El-Nagdi WMA, Haggag KHE, Abd-El-Fattah Al, Abd-El-Khair H (2011) Biological control of Meloidogyne incognita and Fusarium solani in sugar beet. Nematol. Medit. 39: 59-71.

21. Neipp PW, Becker JO (1999) Evaluation of Biocontrol Activity of Rhizobacteria from Beta vulgaris against Heterodera schachtii. J Nematol 31: 54-61.

22. Vary $P$ (1992) Development of genetic engineering in Bacillus megaterium Pp.251-310 in R.H.Doi and M.Mc Gloughlin, eds. Biology of bacilli: Applications to industry. Boston: Butterworth-Heinemann.

23. Kavino M, Harish S, Kumar N, Saravanakumar D, Domodaran T (2007) Rhizophere and endophytic bacteria for induction of systemic resistance of banana plantlets against bunchy top virus. Soil Biol. and Biochmis. 39: 10871098.

24. Bruce RJ, West CA (1989) Elicitation of lignin biosynthesis and is operoxidase activity by pectic fragments in suspension cultures of castor bean. Plant Physio 91: 889-897.

25. Zacheo G, Bleve-Zacheo T, Pacoda D, Orlando C, Durbin RD (1995) The association between heat-induced susceptibility of tomato to Meloidogyne incognita and peroxidase activity. Physiological and Molecular Plant Pathol, 46 491-507.

26. Hassan HAE, Buchenauer $H$ (2007) Induction of resistance to fire blight in apple by acibenzolar-S- methyl and DL-3 aminobutyric acid. J. Plant Dis. Protec. 114: 151-158.

27. Govindappa M, Lokesh S, Ravishankar VR, Rudranaik V, Raju SC (2010) Induction of systemic resistance and management of safflower Macrophomina phaseolina root rot disease by biocontrol agents. Arch. Phytopathol. Plant Prot. 43: $26-40$. 